\title{
EFEKTIVITAS PEMBELAJARAN MICROSOSFT EXCEL BERBASIS INTERAKTIF PADA MATA KULIAH TEKNOLOGI INFORMASI DAN KOMUNIKASI (TIK) \\ (Study Kasus Pada Mahasiswa Manajemen STIE PGRI Dewantara Jombang)
}

Writer:

Rita Mutiarni

Correspondence: rita.dewantara@gmail.com

Institution:

STIE PGRI Dewantara Jombang

EKSIS

Vol XI No 2, 2016

ISSN:

$1907-7513$

http://ejournal.stiedewantara.ac.id/

\begin{abstract}
Research conducted in STIE PGRI Dewantara on a management course aims determines: 1) the application of Microsoft Excelbased interactive learning course on information and communication technology (ICT), 2) the effectiveness of Microsoft Excel-based interactive learning. This research is a descriptive case study approach. Data were obtained through interviews and questionnaires to 30 over three (3) variables that represent effectiveness, namely: 1) Satisfaction Program, 2) Input and Output Level and 3) The success of the program. The survey results revealed that the Microsoft Excel-based interactive learning course on information and communication technology (ICT) obtaining results of the overall assessment of the effectiveness of $80 \%$ under the category of very Effective.
\end{abstract}

Keywords: effectiveness, instructional, interactive, Excel Mirosoft

abstrak

Penelitian yang dilakukuan di STIE PGRI Dewantara pada program studi manajemen ini bertujuan untuk mengetahu: 1) penerapan pembelajaran Microsoft Excel berbasis interaktif pada mata kuliah teknologi informasi dan komunikasi (TIK), 2) efektivitas pembelajaran Microsoft Excel berbasis interaktif. Jenis penelitian ini adalah deskriptif dengan pendekatan studi kasus. Data diperoleh melalui wawancara dan kuisioner kepada 30 atas 3 (tiga) variabel yang mewakili efektivitas, yaitu: 1) Kepuasan Program, 2) Tingkat Input dan Output dan 3) Keberhasilan program. Dari hasil penelitian diketahui bahwa pembelajaran Microsoft Excel berbasis interaktif pada mata kuliah teknologi informasi dan komunikasi (TIK) memperoleh hasil penilaian efektivitas secara keseluruhan sebesar $80 \%$ berada pada kategori sangat efektiv.

Kata kunci: efektivitas, pembelajaran, interaktif, Mirosoft Excel 


\section{A. PENDAhULUAN}

Di zaman modern ini, perkembangan teknologi mempengaruhi kehidupan sehari-hari. Peralihan dari penggunaan sistim manual menjadi sistim komputerisasi telah dimanfaatkan oleh hamper semua organisasi. Hal ini karena pemanfaatan sistim komputeriasi memiliki banyak kelebihan ditinjau dari segi: 1) efektivitas waktu dan biaya, 2) Relevansi, 3) Kejelasan, 4) Integrasi, 5) Standarisasi, 6) Akurasi, 7) Fleksibelitas, dan 8) Keamanan (Bodnar,et al, 2006:459)

Mahasiswa sebagai agen perubahan dituntut untuk lebih menguasai penggunaan sistim komputeriasi agar bisa diaplikasikan untuk mendukung kegiatan perkuliahan serta pekerjaan professional lainnya terutama pada saat mahasiswa memasuki dunia kerja. Hal ini karena, perusahaan menghendaki seluruh komponen yang ada dalam organisasi tersebut, mampu bekerja secara efektif dan efisien. Efektivitas merupakan unsur pokok untuk mencapai tujuan atau sasaran yang telah ditentukan dalam setiap organisasi. Hal ini sesuai dengan pendapat soewarno yang mengatakan bahwa efektivitas adalah pengukuran dalam arti tercapainya tujuan yang telah ditentukan sebelumnya. Pendapat yang sama juga dikemukakan oleh Caster I. Bernard, yang menyatakan bahwa efektivitas adalah tercapainya sasaran yang telah disepakati bersama (Bernard, 1992:207).

STIE PGRI Dewantara sebagai salah satu perguruan tinggi terkemuka di kabupaten Jombang telah membekali para mahasiswanya dengan kemampuan teknologi informasi dan komunikasi (TIK), baik yang berada di program studi (prodi) Akuntansi maupun manajemen. Hal ini tercermin dari muatan kurikulum yang mewajibkan mahasiswa untuk menempuh mata kuliah TIK pada semester 3 (tiga) yang berbobot 3 (tiga) SKS (Satuan Kredit Semester).

Bagi mahasiswa yang berada pada prodi manajemen, pengajaran mata kuliah TIK lebih dititik beratkan pada penguasaan teknis untuk programprogram yang mendukung kemampuan manajerial umum hingga pengambilan keputusan. Oleh karena itu, meskipun mahasiswa pada umumnya telah menempuh mata pelajaran TIK sejak di sekolah dasar hingga menengah, di STIE PGRI Dewantara Jombang, mahasiswa tetap wajib menempuh materi TIK, dengan materi pokok yaitu penguasaan program pengolah angka yaitu Microsoft Excel (Ms. Excel). Meskipun bagi mahasiswa dan masyarakat pada umumnya Ms. Excel bukanlah yang istimewa tetapi pada kenyataanya masih banyak mahasiswa yang belum menguasai program ini dengan baik, terutama untuk menyelesaikan kasuskasus yang berhubungan dengan kegiatan administrai pada perusahaan.

Hal ini karena materi yang telah mereka pelajari sejak dari sekolah dasar hingga menengah masih bersifat dasar serta keterbatasan waktu serta sarana belajar, terutama bagi mahasiswa yang tidak memiliki computer pribadi (Personal Computer - PC) mapun laptop. Oleh karena itu, STIE PGRI Dewantara mendesain sistim perkuliahan materi TIK secara interaktif terutama untuk materi Ms. Excel, sehingga mahasiswa bisa menyerap ilmu lebih banyak dalam waktu yang terbatas tanpa terbebani dengan kewajiban membaca modul untuk menghafal rumus, karena media pembelajaran telah dirancang agar mahasiswa bisa belajar sendiri karena semua petunjuk pengerjaan telah telah ada dalam program.

Penelitian ini bertujuan untuk mengetahui efektivitas penyerapan materi TIK dengan metode interaktif pada 
mahasiswa manajemen di STIE PGRI Dewantara Jombang. Diharapkan, hasil dari penelitian ini akan bisa digunakan untuk mengembangkan metode perkuliahan untuk mata kuliah praktik lainnya.

\section{B. TINJAUAN PUSTAKA Pengertian Efektivitas}

Efektivitas berasal dari kata efektif yang mengandung pengertian dicapainya keberhasilan dalam mencapai tujuan yang telah ditetapkan. Efektivitas dapat dilihat dari berbagai sudut pandang (view point) dan dapat dinilai dengan berbagai cara dan mempunyai kaitan yang erat dengan efisiensi. Efektivitas memiliki pengertian yang berbeda dengan efisiensi. Seperti yang dinyatakan oleh Ibnu Syamsi dalam bukunya "PokokPokok Organisasi dan Manajemen" yang menyatakan bahwa Efektivitas (hasil guna) ditekankan pada efeknya, hasilnya dan kurang memperdulikan pengorbanan yang perlu diberikan untuk memperoleh hasil tersebut. Sedangkan efisiensi (daya guna), penekanannya disamping pada hasil yang ingin dicapai, juga besarnya pengorbanan untuk mencapai hasil tersebut perlu diperhitungkan (Syamsi,.I, 1988:2).

Berdasarkan pendapat di atas, terdapat perbedaan antara efektivitas dan efisiensi. Perbedaan dari efektivitas dan efisiensi yaitu efektivitas menekankan pada hasil atau efeknya dalam pencapaian tujuan, sedangkan efisiensi cenderung pada penggunaan sumber daya dalam pencapaian tujuan.

Menurut pendapat Mahmudi dalam bukunya "Manajemen Kinerja Sektor Publik"mendefinisikan efektivitas adalah hubungan antara output dengan tujuan, semakin besar kontribusi (sumbangan) output terhadap pencapaian tujuan, maka semakin efektif organisasi, program atau kegiatan (Mahmudi, 2005:92). Berdasarkan pendapat tersebut, bahwa efektivitas mempunyai hubungan timbal balik antara output dengan tujuan. Semakin besar kontribusi output, maka semakin efektif suatu program atau kegiatan.

Efektivitas berfokus pada outcome (hasil), program, atau kegiatan yang dinilai efektif apabila output yang dihasilkan dapat memenuhi tujuan yang diharapkan atau dikatakan spending wisely. Markus Zahnd dalam bukunya "Perancangan Kota Secara Terpadu" mendefinisikan perbedaan efektivitas dan efisiensi, yaitu Efektivitas yaitu berfokus pada akibatnya, pengaruhnya atau efeknya, sedangkan efisiensi berarti tepat atau sesuai untuk mengerjakan sesuatu dengan tidak membuang-buang waktu, tenaga dan biaya (Zahnd, 2006:200).

Berdasarkan penjelasan di atas, bahwa efektivitas lebih memfokuskan pada akibat atau pengaruh sedangkan efisiensi menekankan pada ketepatan mengenai sumber daya, yaitu mencakup anggaran, waktu, tenaga, alat dan cara supaya dalam pelaksanaannya tepat waktu

\section{Ukuran Efektivitas}

Keluaran (output) yang dihasilkan lebih banyak bersifat keluaran (output) tidak berwujud (intangible) yang tidak mudah untuk dikuantifikasi, maka pengukuran efektivitas sering menghadapi kesulitan. Kesulitan dalam pengukuran efektivitas tersebut karena pencapaian hasil (outcome) seringkali tidak dapat diketahui dalam jangka pendek, akan tetapi dalam jangka panjang setelah program berhasil, sehingga ukuran efektivitas biasanya dinyatakan secara kualitatif (berdasarkan pada mutu) dalam bentuk pernyataan saja (judgement), artinya apabila mutu yang dihasilkan baik, maka efektivitasnya baik pula.

Menurut pendapat David Krech, Ricard S. Cruthfied dan Egerton L. Ballachey dalam bukunya "Individual 
and Society" yang dikutip Sudarwan Danim dalam bukunya "Motivasi Kepemimpinan dan Efektivitas Kelompok" menyebutkan ukuran efektivitas, sebagai berikut:

1. Jumlah hasil yang dapat dikeluarkan, artinya hasil tersebut berupa kuantitas atau bentuk fisik dari organisasi, program atau kegiatan. Hasil dimaksud dapat dilihat dari perbandingan (ratio) antara masukan (input) dengan keluaran (output).

2. Tingkat kepuasan yang diperoleh, artinya ukuran dalam efektivitas ini dapat kuantitatif (berdasarkan pada jumlah atau banyaknya) dan dapat kualitatif (berdasarkan pada mutu).

3. Produk kreatif, artinya penciptaan hubungannya kondisi yang kondusif dengan dunia kerja, yang nantinya dapat menumbuhkan kreativitas dan kemampuan.

4. Intensitas yang akan dicapai, artinya memiliki ketaatan yang tinggi dalam suatu tingkatan intens sesuatu, dimana adanya rasa saling memiliki dengan kadar yang tinggi.(Danim, 2004:119120).

Berdasarkan uraian di atas, bahwa ukuran daripada efektifitas harus adanya suatu perbandingan antara masukan dan keluaran, ukuran daripada efektifitas harus adanya tingkat kepuasan dan adanya penciptaan hubungan kerja yang kondusif serta intensitas yang tinggi, artinya ukuran daripada efektivitas adanya keaadan rasa saling memiliki dengan tingkatan yang tinggi.

Efektivitas merupakan usaha pencapaian sasaran yang dikehendaki (sesuai dengan harapan) yang ditujukan kepada orang banyak dan dapat dirasakan oleh kelompok sasaran yaitu masyarakat. Hal ini sejalan dengan pendapat Duncan yang dikutip Richard M.Steers dalam bukunya "Efektivitas Organisasi" mengatakan mengenai ukuran efektivitas, sebagai berikut:
1. Pencapaian Tujuan

2. Integrasi

3. Adaptasi (Duncan, dalam Steers 1985:53).

Menurut Cambel J.P, Pengukuran efektivitas secara umum dan yang paling menonjol adalah :

1. Keberhasilan program

2. Keberhasilan sasaran

3. Kepuasan terhadap program

4. Tingkat input dan output

5. Pencapaian tujuan menyeluruh

(Cambel, 1989:121)

Sejarah dan Perkembangan Microsoft Excel

Microsoft Excel (Ms. Excel) merupakan sebuah aplikasi untuk membuat atau menyunting spreadsheet yang dikembangkan oleh Microsoft untuk digunakan pada sistem operasi Microsoft Windows maupun Macintosh. Fitur-fitur yang ada di dalamnya ialah kalkulasi, alat-alat pembuat graf, pivot table, dan sebuah bahasa pemrograman macro yaitu "Visual Basic" untuk aplikasi.

Peluncuran dari versi awal Microsoft Excel dimulai tepat ketika Multiplan gagal di pasaran tepatnya pada tanggal 30 September 1985 sehingga Microsoft kemudian meluncurkan versi pertama Microsoft Excel untuk sistem operasi Macintosh. Versi Windows baru dirilis pada November 1987 dengan langsung meloncat ke versi 2.0 demi mengimbangi versi Macintosh yang sudah menyentuh versi 2.2 pada saat itu.

Kesalahan Multiplan ada pada lambatnya mereka membuat versi Windows, memberi celah pada Microsoft Excel masuk ke daerah tersebut. Hal ini dibuktikan dengan kemampuan yang ditunjukkan oleh Microsoft Excel dimana ia berhasil mengalahkan Lotus 1-2-3 dalam sisi penjualan pada tahun 1988 dan membuat Microsoft ada pada posisi pemimpin di bidang pengembangan program untuk PC. Awalnya, Excel menuai banyak pengaduan karena dinilai 
melanggar hak cipta nama dari sebuah perusahaan finansial, dan karena itu namanya diubah menjadi Microsoft Excel.

Versi pertama Microsoft Excel adalah eksklusif untuk komputerkomputer yang menggunakan Macintosh sebagai sistem operasinya dan dirilis pada tahun 1985. Versi ini kembali berlanjut dengan dirilisnya Excel 2.0 pada tahun 1987 yang ditujukan untuk komputer dengan sistem operasi berbasis Windows dimana angka 2 (dua) dipilih untuk mengejar versi yang ada pada program yang dirilis untuk sistem operasi Macintosh yaitu Excel 2.2. Selanjutnya, Microsoft melahirkan Excel 3.0 pada tahun 1990 dan Excel 4.0 pada tahun 1992. Di tahun 1993 inilah Microsoft pertama kali menyelipkan "Visual Basic for Application” pada Excel 5.0 yang mampu membuat sebuah pekerjaan otomatis di Excel dan menyajikan UserDefined Functions (UDF) untuk digunakan dalam worksheet. Penambahan $V B A$ ini dinilai sebagai salah satu penambahan yang paling kuat pada masa itu, sayangnya kelebihan ini juga menjadi titik lemah dimana Excel menjadi sasaran empuk bagi virus-virus macro. Karena banyak kejadian dan laporan yang mengeluhkan tentang virusvirus macro ini, Mircrosoft akhirnya membuat sebuah keputusan terlambat dengan menambahkan vitur untuk mematikan macro secara keseluruhan.

Sebelum Microsoft meluncurkan sebuah piranti lunak yang mampu melakukan kapabilitas Microsoft Excel, sebuah piranti lunak lainnya sudah terlebih dulu muncul dan memiliki nama, yaitu VisiCalc yang awalnya dirilis untuk Apple II dan disebut sebagai aplikasi yang mengubah komputer mikro dari hanya hobi bagi para antusias komputer menjadi sebuah alat bisnis serius. Piranti bernama VisiCalc tersebut juga disebutsebut sebagai aplikasi terdahsyat dari
Apple II pada masa itu karena berhasil terjual sebanyak 700.000 copy dalam waktu 6 (enam) tahun.

Hampir tidak ada terobosan baru pada Excel hingga pada versi 12 yang dirilis tahun 2007. Setelah beberapa versi hanya mengalami peningkatan minor, versi 12 merupakan sebuah perubahan yang amat jauh dibandingkan versi sebelumnya terutama pada bagian menu yang menggunakan sistem Ribbon. Selain itu, pada versi baru ini juga ditambahkan format fail Office Open XML yaitu ".xlsm" untuk sebuah workbook tanpa macro dan ".xlsx" untuk yang menggunakan Macro.

\section{Metode Pembelajaran Microsoft Excel} Secara Interaktif

Program Ms. Excel sudah dikenal masyarakat termasuk bagi para mahasiswa karena sebagian besar, mahasiswa telah mempelajari ini sebagai bagian dari kurikulum sekolah di tingkat dasar maupun menengah. Umumnya, mahasiswa mempelajari program $M s$. Excel bersama dengan program Microsoft yang terkenal lainnya yaitu program pengolah kata (Microsoft Word). Tetapi, pada kenyataannya penyerapan materi pembelajaran program Microsoft Word (Ms. Word) masih lebih baik jika dibanding dengan program Ms. Excel. Hal ini disebabkan karena beberapa faktor antara lain: 1) Tingkat kesulitan materi, 2) Keterbatasan waktu, 3) Kemampuan berbahasa Inggris.

Pada program Ms. Excel, pengguna harus menghapal rumus/formula yang berbeda untuk tiap fungsi kalkulasi. Sehingga, metode pembelajaran yang ada di tingkat sekolah adalah dengan mengetik dan mengajarkan formula untuk kasus yang berbeda. Apabila pengguna lupa, maka tidak ada jalan lain kecuali membuka kembali buku materi pembelajaran yang pernah didapat.

Melihat kenyataan ini, maka peneliti mengembangkan metode 
pembelajaran Ms. Excel secara interkatif untuk kalangan mahasiswa. Hal ini sesuai untuk kultur perkuliahan dimana mahasiswa dituntut untuk lebih aktif, tidak tergantung kepada dosen pengampu, dan yang lebih penting, mahasiswa mampu memanfaatkan untuk penyelesaian tugas-tugas administratif

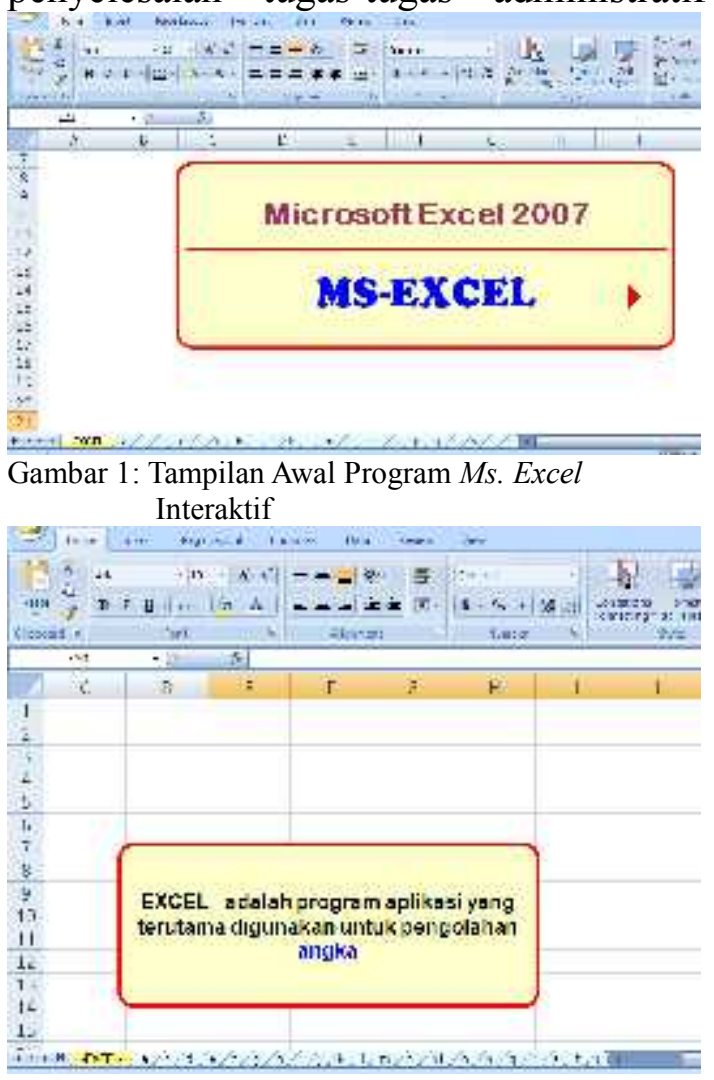

Gambar 2: Sheet pada program dan manajerial untuk pengambilan keputusan.

Materi Ms. Excel interaktif disusun dengan cara bookless, yaitu mahasiswa tidak lagi perlu membaca modul pendamping materi, karena semua materi telah diketik dan dilejaskan secara gambar pada gambar berikut:

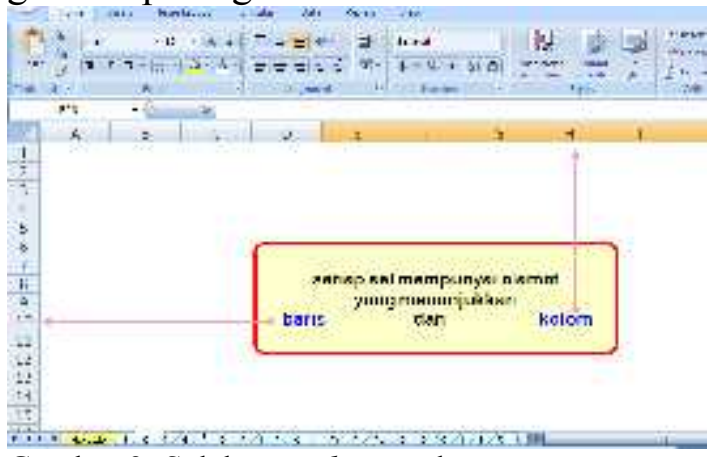

Gambar 3: Salah satu sheet pada program

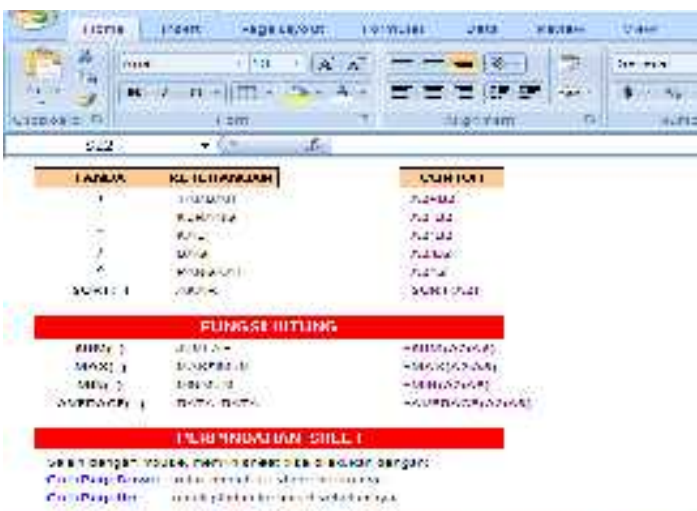

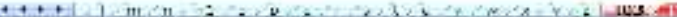
Gambar 4: Petunjuk kalkulasi dasar pada program

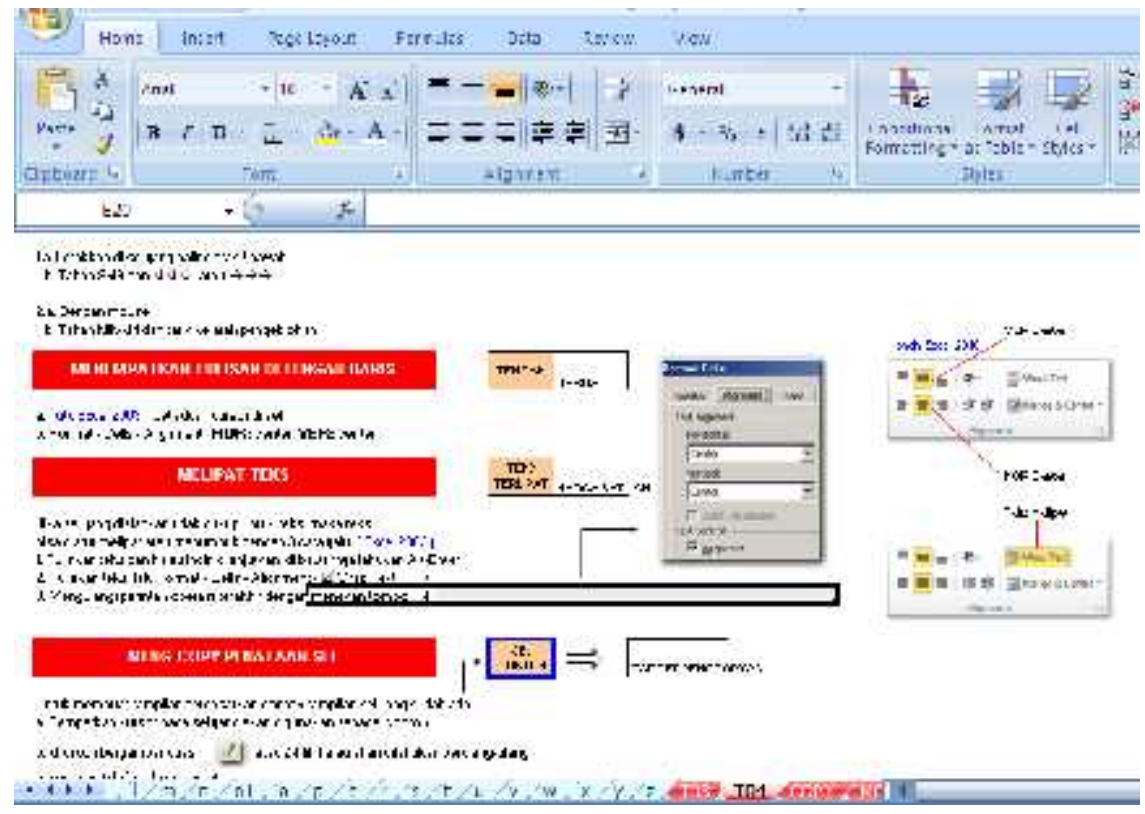


Gambar 5: Petunjuk operasi lainnya pada program

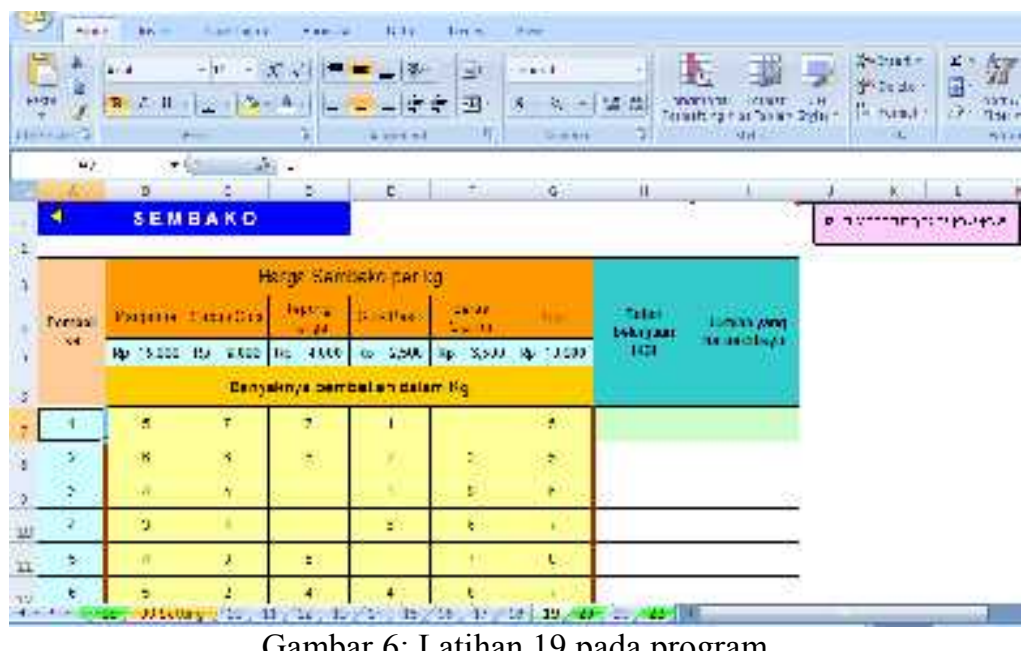

Gambar 6: Latihan 19 pada program

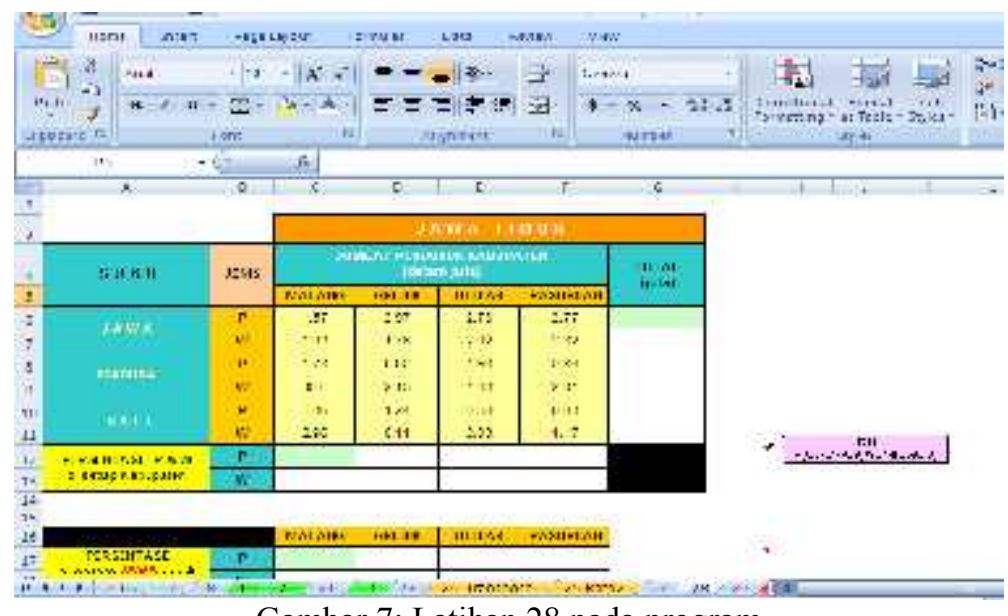

Gambar 7: Latihan 28 pada program

Pada gambar-gambar diatas, pengerjaan berupa "segitiga merah kecil" tampak bahwa modul pelatihan disiapkan yang ada pada alamat sel tertentu, berisi dalam 1 (satu) lembar kerja (workbook) petunjuk pengerjaannya. Selain itu, yang terdiri dari beberapa sheet. Petunjuk program ini telah di olah sedemikian rupa dan keterangan tata cara pengoperasian Ms. Excel disusun mulai dari sangat dasar (gambar 1, 2, 3 dan selanjutnya) hingga pada latihan soal seperti yang tampak pada gambar diatas.

Di tiap-tiap soal latihan, modul sehingga mahasiswa bisa mengkoreksi sendiri pekerjaannya, karena apabila benar maka sel akan berwarna hijaau dan apabila pekerjaannya salah, maka sel otomatis akan berwarna merah, sebagai mana yang tampak pada gambar berikut: telah dilengkapi dengan petujuk

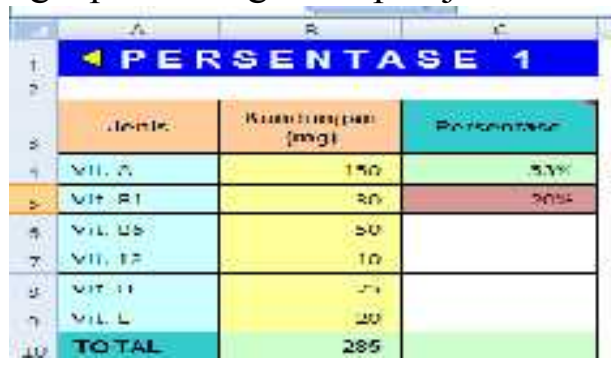

Gambar 8: Latihan 27 pada program dengan pengerjaan secara benar dan salah 


\section{Hipotesis}

Hipotesis yang dibangun pada penelitian ini adalah: Diduga, Pembelajaran Micrososft Excel Berbasis Interaktif Pada Mata Kuliah Teknologi Informasi Dan Komunikasi (TIK) Memberikan Hasil Yang Efektif

\section{METODE PENELITIAN Jenis Penelitan}

Penelitian ini adalah penelitian deskriptif dengan pendekatan kualitatif, dengan pendekatan case study (studi kasus).

\section{Lokasi dan Waktu Penelitian}

Penelitian ini dilakukan di STIE PGRI Dewantara Jombang yang beralamat di jalan Prof. M. Yamin/77 Jombang pada bulan Januari-Maret 2016.

\section{Populasi dan sampel}

Populai dalam penelitian ini adalah mahasiswa program studi (Prodi) manajemen angkatan 2014 sebanyak 240 mahasiswa, sedangkan yang dijadikan sampel dalam penelitian ini adalah 30 responden.

\section{Jenis dan Sumber Data}

Jenis data dalam penelitian ini adalah data kualitatif berupa hasil jawaban responden mengenai metode pembelajaran Micrososft Excel berbasis interaktif pada mata kuliah Teknologi Informasi Dan Komunikasi (TIK) yang dikuantitatifkan menjadi angka-angka. Sumber data yang digunakan dalam penelitian ini adalah data primer yaitu berupa hasil wawancara dan hasil jawaban responden yang diperoleh dalam survei dengan menggunakan kuesioner.

\section{Operasionalisasi Variabel dan Indikator} Operasionalisasi variabel dan indicator pada penelitian ini adalah:

\begin{tabular}{|c|c|}
\hline Variabel & Indikator \\
\hline 1. Kepuasan terhadap program & $\begin{array}{l}\text { 1. Presensi Mahasiswa } \\
\text { 2. Kehadiran tepat waktu } \\
\text { 3. Antusiasme di kelas }\end{array}$ \\
\hline 2. Tingkat input dan output & $\begin{array}{l}\text { 1. Durasi penyelesaian latihan sebelum dan } \\
\text { sesudah program dimulai } \\
\text { 2. Jumlah latihan yang diselesaikan diakhir } \\
\text { program }\end{array}$ \\
\hline $\begin{array}{l}\text { 3. Keberhasilan program } \\
\text { (Cambel, 1989:121) }\end{array}$ & $\begin{array}{l}\text { 1. Kemampuan mahasiswa memahami } \\
\text { program } \\
\text { 2. Kemampuan mahasiswa mengerjakan } \\
\text { latihan }\end{array}$ \\
\hline
\end{tabular}

\section{Metode Pengumpulan Data}

Metode pengumpulan data yang digunakan:

1. Wawancara dengan kepala program studi (Ka. Prodi) manajemen, dipergunakan untuk memperoleh data mengenai Learning Output (LO) atau capaian yang diharapkan dari mata kuliah TIK,

2. Kuesioner, dipergunakan untuk mengetahui penilaian mahasiswa tentang pembelajaran Micrososft
Excel berbasis interaktif pada mata kuliah teknologi informasi dan komunikasi (TIK).

\section{Teknik Analisa Data}

Teknik analisis yang digunakan dalam penelitian ini adalah teknik analisis kuantitaif. Untuk mengkuantitatifkan data penilaian responden yang sebelumnya bersifat kualitatif, maka pengukuran dilakukan dengan menggunakan skala likert. 
Penentuan besarnya persentase efektivitas pembelajaran Micrososft Excel berbasis interaktif pada mata kuliah teknologi informasi dan komunikasi (TIK) untuk masing- masing indikator yang dinilai dengan prosedur perhitungan:

1. Dicari jumlah skor yang diperoleh untuk masing-masing aspek penilaian

2. Dari kuesioner tersebut ditentukan jumlah skor ideal yaitu jumlah skor bila semua responden menjawab skor tertinggi pada setiap butir pernyataan dalam setiap aspek yang dinilai

3. Menentukan persentase efektivitas pembelajaran Micrososft Excel berbasis interaktif pada mata kuliah teknologi informasi dan komunikasi (TIK)

$=\frac{\text { jumlah skor yang diperoleh }}{\text { jumlah skor ideal }} \times 100 \%$

(Sugiyono, 2012)

Kriteria efektivitas pembelajaran Micrososft Excel berbasis interaktif pada mata kuliah teknologi informasi dan komunikasi (TIK) dapat dilihat pada tabel berikut:

Tabel 2: Persentase Efektivitas Pembelajaran Micrososft Excel Berbasis Interaktif Pada Mata Kuliah Teknologi Informasi Dan Komunikasi (TIK)

\begin{tabular}{ll}
\hline Kriteria & Kategori \\
\hline $80 \%<\mathrm{X} \leq 100 \%$ & Sangat efektif \\
\hline $60 \%<\mathrm{X} \leq 80 \%$ & Efektif \\
\hline $40 \%<\mathrm{X} \leq 60 \%$ & Ragu-ragu \\
\hline $20 \%<\mathrm{X} \leq 40 \%$ & Tidak efektif \\
\hline $0 \% \leq \mathrm{X} \leq 20 \%$ & $\begin{array}{l}\text { Sangat tidak } \\
\text { efektif }\end{array}$ \\
\hline
\end{tabular}

Sumber: Sugiyono (2012)

\section{HASIL PENELITIAN DAN PEMBAHASAN}

STIE PGRI Dewantara Jombang adalah salah satu perguruan tinggi swasta terkemuka yang berada di kabupaten
Jombang. STIE PGRI Dewantara Jombang mempunyai 2 (dua) program studi (prodi) yaitu akuntansi dan manajemen.

Sebagai perguruan tinggi yang telah menerapkan kurikulum berbasis KKNI, STIE PGRI Dewantara Jombang dituntut untuk menghasilkan lulusan yang berkualitas sebagaimana yang tercermin dalam visi dan misinya.

Pada prodi manajemen, mahasiswa tidak dibekali dengan ilmu pada tingkatan manajerial, tetapi juga dibekali dengan berbagai softskill yang aplikatif untuk membantu penyelesaian soal administratif guna mendukung pengambilan keputusan, karena umumnya mahasiswa merintis karir dari level dasar sebelum mencapai posisi sebagai seorang manajer. Untuk itu, mahasiswa perlu dibekali dengan kemampuan dasar sebagai seorang staf yang banyak berhubungan dengan pekerjaan administrative guna mendukung pengambilan keputusan bagi manajer.

Mata kuliah Teknik Informasi dan Komunikasi (TIK) di STIE PGRI Dewantara Jombang membekali mahasiswa dengan kemampuan dasar pengoperasian computer khusunya untuk program pengolah angka (kalkulasi). Dengan keterbatasan jumlah tatap muka tetapi mahasiswa dituntut untuk menyerap materi lebih banyak, maka dibuatlah model pembelajaran TIK secara interaktif, dengan metode perkuliahan:

1. Pertemuan terbatas ( $10 \mathrm{X}$ tatap muka (a) 90 menit) untuk mengerajakan 50 jenis latihan soal

2. Penjelasan ditulis pada program \& tanpa modul

3. Petunjuk penyelesaian latihan ada di tiap cell

4. Otomatisasi penilaian pada soal yang dikerjaan

Setelah perkuliahan berakhir, peneliti menganalisa efektivitas 
pembelajaran Micrososft Excel berbasis interaktif pada mata kuliah teknologi informasi dan komunikasi (TIK) dengan variabel: 1) Kepuasan terhadap program, 2) Tingkat input dan output, 3) Keberhasilan program. Hasil yang diperoleh berdasarkan jawaban responden atas pernyataan yang diajukan untuk masing-masing variabel adalah sebagai berikut:

Tabel 3: Rekapitulasi Jawaban Responden Atas Variabel Kepuasan Program

\begin{tabular}{lcc}
\multicolumn{1}{c}{ Indikator } & $\begin{array}{c}\text { Total } \\
\text { Skor }\end{array}$ & $\begin{array}{c}\text { Persentase } \\
\text { Efektivitas }\end{array}$ \\
\hline Presensi Mahasiswa & 123 & $123 / 150=82 \%$ \\
\hline $\begin{array}{l}\text { Kehadiran tepat } \\
\text { waktu }\end{array}$ & 113 & $113 / 150=75 \%$ \\
\hline Antusiasme di kelas & 124 & \multicolumn{1}{c}{$124 / 150=83 \%$} \\
\hline Skor Rata-rata & \multicolumn{3}{c}{$80 \%$} \\
\hline $\begin{array}{l}\text { Sumber: Data primer diolah, 2016 } \\
\text { Dari tabel diatas tampak bahwa }\end{array}$ \\
jawaban responden atas variabel
\end{tabular}

kepuasan program menunjukkan skor rata-rata $80 \%$. Hal ini disimpulkan bahwa efektivitas pembelajaran Micrososft Excel berbasis interaktif pada mata kuliah teknologi informasi dan komunikasi (TIK) dilihat dari variabel kepuasan program adalah sangat efektif.

Hasil yang diperoleh dari jawaban responden atas pernyataan yang diajukan untuk Variabel Tingkat Input Dan Output adalah sebagai berikut:

Tabel 4: Rekapitulasi Jawaban Responden Atas

Variabel Tingkat Input Dan Output

\begin{tabular}{lcc}
\hline \multicolumn{1}{c}{ Indikator } & $\begin{array}{c}\text { Total } \\
\text { Skor }\end{array}$ & $\begin{array}{c}\text { Persentase } \\
\text { Efektivitas }\end{array}$ \\
\hline $\begin{array}{l}\text { Durasi penyelesaian } \\
\text { latihan sebelum dan } \\
\text { sesudah program } \\
\text { dimulai }\end{array}$ & $126 / 150=84 \%$ \\
\hline $\begin{array}{l}\text { Jumlah latihan yang } \\
\text { diselesaikan diakhir } \\
\text { program }\end{array}$ & 117 \\
\hline Skor Rata-rata & $81 \%$ \\
\hline
\end{tabular}

Sumber: Data primer diolah, 2016

Dari tabel diatas tampak bahwa jawaban responden atas variabel tingkat input dan output menunjukkan skor ratarata $81 \%$. Hal ini disimpulkan bahwa efektivitas pembelajaran Micrososft
Excel berbasis interaktif pada mata kuliah teknologi informasi dan komunikasi (TIK) dilihat dari variabel tingkat input dan output adalah sangat efektif.

Hasil yang diperoleh dari jawaban responden atas pernyataan yang diajukan untuk Variabel Keberhasilan Program adalah sebagai berikut:

Tabel 5: Rekapitulasi Jawaban Responden Atas Variabel Keberhasilan Program

\begin{tabular}{llc}
\hline Indikator & $\begin{array}{l}\text { Total } \\
\text { Skor }\end{array}$ & $\begin{array}{c}\text { Persentase } \\
\text { Efektivitas }\end{array}$ \\
\hline $\begin{array}{l}\text { Kemampuan } \\
\text { mahasiswa } \\
\text { memahami program }\end{array}$ & 122 & $122 / 150=81 \%$ \\
\hline $\begin{array}{l}\text { Kemampuan } \\
\text { mahasiswa } \\
\text { mengerjakan latihan }\end{array}$ & 114 & $114 / 150=76 \%$ \\
\hline Skor Rata-rata & & $79 \%$ \\
\hline
\end{tabular}

Sumber: Data primer diolah, 2016

Dari tabel diatas tampak bahwa jawaban responden atas variabel Keberhasilan Program menunjukkan skor rata-rata $79 \%$. Hal ini disimpulkan bahwa efektivitas pembelajaran Micrososft Excel berbasis interaktif pada mata kuliah teknologi informasi dan komunikasi (TIK) dilihat dari variabel Keberhasilan Program adalah efektif.

Hasil yang diperoleh dari jawaban responden atas perrnyataan yang diajukan untuk seluruh variabel dalam penelitian ini adalah sebagai berikut:

Tabel 6: Rekapitulasi Jawaban Responden Atas Seluruh Variabel

\begin{tabular}{|c|c|}
\hline Variabel & $\begin{array}{c}\text { Skor Rata- } \\
\text { Rata }\end{array}$ \\
\hline Kepuasan Program & $80 \%$ \\
\hline Tingkat Input Dan Output & $81 \%$ \\
\hline Keberhasilan Program & $79 \%$ \\
\hline Skor Rata-rata & $80 \%$ \\
\hline
\end{tabular}

Dari tabel diatas tampak bahwa jawaban responden atas seluruh variabel menunjukkan skor rata-rata $80 \%$. Hal ini disimpulkan bahwa efektivitas pembelajaran Micrososft Excel berbasis interaktif pada mata kuliah teknologi 
informasi dan komunikasi (TIK) dilihat dari variabel Keberhasilan Program adalah sangat efektif.

\section{Pembahasan}

Penerapan pembelajaran Micrososft Excel berbasis interaktif pada mata kuliah teknologi informasi dan komunikasi (TIK) di STIE PGRI Dewantara Jombang adalah sangat efektiv. Hal ini dapat dilihat dari hasil analisis data tentang efektivitas pembelajaran Micrososft Excel berbasis interaktif pada mata kuliah teknologi informasi dan komunikasi (TIK) yang diukur dengan 3 (tiga) variabel, yaitu Kepuasan Program, Tingkat Input dan Output serta Keberhasilan Program, menunjukkan nilai rerata sebesar $80 \%$ dan termasuk dalam kategori sangat efektif.

Untuk variabel kepuasan program, menunjukkan bahwa metode perkuliahan ini sangat efektif. Hal ini terlihat dari indikator tingkat peresensi mahasiswa dan antusiasme di kelas menunjukkan skor diatas $80 \%$ yang berarti sangat efektif. Untuk variabel tingkat input dan output, menunjukkan bahwa metode perkuliahan ini juga sangat efektif. Hal ini terlihat dari indikator durasi penyelesaian latihan sebelum dan sesudah program dimulai serta Jumlah latihan yang diselesaikan diakhir program, menunjukkan skor rerata $81 \%$ yang berarti sangat efektif. Sedangkan untuk variabel keberhasilan program, menunjukkan bahwa metode perkuliahan ini juga efektif. Hal ini terlihat dari indikator kemampuan mahasiswa memahami program dan kemampuan mahasiswa mengerjakan latihan menunjukkan skor rerata 79\% yang berarti efektif. Apabila seluruh jawaban dari responden dilihat dari nilai rerata seluruh variabel dalam penelitian ini yang menunjukkan nilai $80 \%$ dan berarti sangat efektif, maka disimpulkan bahwa penerapan pembelajaran Micrososft Excel berbasis interaktif pada mata kuliah teknologi informasi dan komunikasi (TIK) di STIE PGRI Dewantara Jombang adalah sangat efektif.

\section{E. PENUTUP}

Dari hasil penelitian diatas disimpulkan bahwa penerapan pembelajaran Micrososft Excel berbasis interaktif pada mata kuliah teknologi informasi dan komunikasi (TIK) di STIE PGRI Dewantara Jombang adalah sangat efektiv dengan skor rerata sebesar $80 \%$. Hal ini terlihat dari hasil pengukuran efektivitas yang menggunakan 3 (tiga) variabel yaitu: 1) Variabel Kepuasan Program yang menunjukkan skor rerata sebesar $80 \%$ yang berarti sangat efeketif, 2) Variabel Tingkat input dan Output yang menunjukkan skor rerata sebesar 81\% yanga juga berarti sangat efektif, dan 3) Variabel Keberhasilan Program yang menunjukkan skor rerata sebesar $79 \%$ yang berarti efektif

Dari simpulan diatas, disarankan kepada pihak STIE PGRI Dewantara khususnya program studi manajemen untuk terus mengembangkan sistim perkuliahan ineteraktif karena terbukti sangat efektif penyerapannya bagi mahasiswa. Selain itu, disarankan agar program ini juga bisa diterapkan kepada mahasiswa program studi akuntansi tentunya dengan soal-soal latihan yang disesuaikan dengan kebutuhan mahasiswa akuntansi, agar mahasiswa akuntansi juga mempunyai bekal lebih berupa softskill penyelesaian kasus-kasus akuntansi dengan pendekatan Ms. Excel.

\section{DAFTAR PUSTAKA}

Bernard, I, Caster. 1992. Organisasi dan Manajemen Struktur, Prilaku dan Proses. Jakarta: Gramedia.

Cambel, JP. 1989. Riset dalam Efektivitas Organisasi, terjemahan Salut Simamora. Jakarta: Erlangga

Danim, Sudarwan. 2004. Motivasi Kepemimpinan dan Efektivitas 
Kelompok. Bengkulu: PT Rineka Cipta

George H, Bodnar dan Hopwood William S. 2006. Sistim Informasi Akuntansi. Edisi Kesembilan. Yogyakarta: Andi Offset

Mahmudi, Syamsu. 2005. Manajemen Kinerja Sektor Publik, Edisi I. Yogyakarta: Penerbit Buku UPPAMP YKPN

Steers, Richard M. 1985. Efektivitas Organisasi, Jakarta: Erlangga

Syamsi, Ibnu. 1988. Pokok-pokok Manajemen Perlengkapan. Yogyakarta: Balai Pembangunan Administrasi

Zahnd, Markus. 2006. Perancangan Kota Secara Terpadu. Yogyakarta: Kanisius

Analisis Efektivitas Pengolahan Data Elektronik Dengan Program
MYOB Pada UD. Widya Pratamadi Gianyar. Ni Luh Md.Pitria Dewi

Implementasi Akuntansi Berbasis

Komputer Pada Koperasi Di Kabupaten Klaten. Shandy Marsono Dan Jumadi STIE AUB Surakarta

Penerapan Electronic Data Processing Dalam Sistem Informasi Akuntansi Pada PT. Mediadatacorp. Rudy Irsian.

http://e-journal.stie-aub.ac.id diakses tanggal 3 Maret 2016

http://portalsejarah.com diakses tanggal 3 Maret 2016

http://repository.usu.ac.id diakses tanggal 8 Maret 2016

http://uda.ac.id/jurnal diakses tanggal 5 Maret 2016

http://xcelmedia.net diakses tanggal 3 Januari 2016 